\title{
PENERAPAN QUANTUM LEARNING UNTUK MENINGKATKAN AKTIVITAS BELAJAR DAN KEMAMPUAN MENULIS HASIL KARANGAN DESKRIPSI PADA SISWA KELAS IX SMP
}

\author{
Oleh \\ Ni Nyoman Suwandiari \\ SMP Negeri 2 Kubu \\ e-mail:suwandiarinyoman@yahoo.com
}

\begin{abstract}
ABSTRAK
Penelitian ini dilatarbelakangi oleh rendahnya aktivitas dan kemampuan menulis karangan deskripsi siswa. Penelitian ini bertujuan untuk meningkatkan aktivitas dan kemampuan menulis karangan deskripsi siswa melalui penerapan quantum learning dalam pembelajaran. Aktivitas belajar siswa diambil dengan menggunakan pedoman observasi. Data karangan deskripsi diperoleh dari kemampuan siswa membuat karangan deskripsi yang diberikan ada akhir siklus. Data yang terkumpul dianalisis menggunakan rumus statistik. Hasil pelaksanaan tindakan pada penelitian ini menunjukkan bahwa (1) Penerapan Quantum Learning dapat meningkatkan aktivitas belajar siswa. Pada siklus I rata-rata aktivitas belajar siswa adalah 70 dengan kualifikasi cukup aktif. Siklus II rata-rata aktivitas belajar siswa adalah 86 dengan kualifikasi aktif (2) Penerapan Quantum Learning dapat meningkatkan kemampuan menulis karangan deskripsi siswa. Pada siklus I rata-rata kemampuan menulis karangan deskripsi siswa adalah 60 dengan kualifikasi cukup. Siklus II rata-rata kemampuan menulis karangan deskripsi siswa adalah 79 dengan kualifikasi baik. Dengan demikian Penerapan Quantum Learning dapat meningkatkan aktivitas belajar dan kemampuan menulis karangan deskripsi.
\end{abstract}

Kata kunci: Quantum Learning, Aktivitas Belajar, Kemampuan Menulis

\begin{abstract}
This research was motivated by student's lack of participationand low writing description text ability. This study aims to improve the students activity and writing description text ability through the application of quantum learning in learning activities. The data in this research were collected by observation method and writing description text which was accompanied by observation and writing guidance on student learning activity. The collected data were analyzed by using descriptive statistic. The results of action implementation in this study indicate that (1) Application of quantum learning can improve student's learning activity. In cycle I the average of students' learning activity was 70 which is quite active; whereas in cycle II the average of student's learning activity was 86 which was classified as active. (2) The application of quantum learning can improve
\end{abstract}

Jurnal IKA | 50

Penerapan Quantum Learning Untuk Meningkatkan. Ni Nyoman Suwandiari (50-68) 
student's writing description text ability. In cycle I, the result showed that the average score of student's writing description text ability was 60, while in the second cycle the average score of student's writing description text ability was 79. Thus the application of quantum learning can improve the learning activity and student's writing description text ability.

Keywords: Quantum Learning, learning activity, writing ability

\section{PENDAHULUAN}

Untuk meningkatkan keterampilan manusia dalam berbahasa, terdapa tempat komponen keterampilan yang harus diperhatikan dan dilatih, yaitu keterampilan menyimak (listening skills), berbicara (speaking skills), membaca (reading skills), dan menulis (writing skills). Berdasakan aktivitasnya, membaca dan menyimak tergolong ke dalam keterampilan berbahasa yang bersifat reseptif, sedangkan keterampilan berbicara dan menulis termasuk keterampilan berbahasa yang bersifat produktif (Panji, 2007:1).

Berdasarkan keempat keterampilan berbahasa tersebut, keterampilan menulis merupakan kegiatan berbahasa yang memerlukan perhatian khusus. Menulis sangat dibutuhkan dalam kehidupan seseorang. Menulis bukan hanya diperlukan pada saat sekolah saja tetapi dibutuhkan juga pada saat seseorang telah menyelesaikan pendidikannya dan terjun dalam kehidupan masyarakat. Dalam menuangkan ide melalui tulisan, tidaklah semudah seperti mengungkapkan ide melalui lisan, sehingga untuk menguasainya diperlukan latihan yang berkesinambungan. Dengan demikian, menulis bukan merupakan kegiatan yang menyulitkan lagi dan orang menjadi terbiasa dalam menulis. Sebagaimana tercantum dalam KTSP tujuan pembelajaran bahasa Indonesia diarahkan untuk meningkatkan kemampuan peserta didik dalam berkomunikasi dengan menggunakan bahasa Indonesia yang baik dan benar, baik secara lisan maupun tulisan.

Menulis telah diajarkan dalam bangku sekolah pada saat seseorang berada disekolah dasar sampai sekolah lanjutan, tetapi pembelajaran menulis masih dirasa kurang berhasil sepenuhnya. Kenyataan tersebut, seperti yang diungkapkan Suryanto dkk (dalam Nurhayati,1998:13), bahwa menulis sangat diperlukan oleh 
seseorang. Melalui lembaga sekolah, menulis diajarkan melalui mata pelajaran bahasa Indonesia. Pada sisi lain, pembelajaran bahasa Indonesia dapat dikatakan belum berhasil sepenuhnya. Kekurangberhasilan tersebut banyak terjadi pada pencapaian aspek penggunaan bahasa Indonesia. Sebagian besar kekurangberhasilan siswa dalam pembelajaran bahasa Indonesia karena masih sulitnya menggunakan bahasa Indonesia secara aktif dan produktif terutama dalam kegiatan menulis.

Hal di atas terjadi pula di SMP Negeri 2 Kubu. Hasil belajar siswa masih tergolong rendah. Padahal kriteria ketuntasan minimal yang ditetapkan SMP Negeri 2 Kubu Masih tergolong rendah. Siswa kelas IX B hanya mampu mencapai rata-rata hasil belajar 6,75 dengan ketuntasan klasikal siswa sebesar 65\%. Hasil ini jelas tidak menggembirakan karena kelas IX B akan segera menempuh ujian nasional.

Melalui diskusi dengan tim MGMP Bahasa Indonesia di SMP Negeri 2 Kubu diketahui hal-hal berikut. Pertama, Siswa umumnya mengalami kesulitan dalam menulis dan pada dasarnya kegiatan menulis tidak terlalu menarik bagi mereka. Mereka sulit dalam membedakan antara karangan deskripsi dengan karangan lainnya. Mereka merasa sulit dalam memilih kata dan masih sulit dalam merangkaikan kalimat. Kesalahan banyak terjadi pula pada penggunaan huruf kapital dan tanda baca. Ejaan yang digunakan masih tidak sesuai, mereka sering menggunakan bahasa SMS (Short Massage Service) dengan alasan karena sudah terbiasa seperti itu. Selain itu, tidak adanya pembelajaran khusus mengenai EYD (Ejaan Yang Dibenarkan) menjadi salah satu pemicu hal tersebut. Guru tidak mempunyai cara atau trik lain untuk mengajarkan EYD. Hasilnya, ketika anak-anak disuruh membuat karangan dengan keharusan menggunakan kaidah penulisan yang benar, mereka tidak mampu menuangkan gagasannya dan ketika anak-anak disuruh menuangkan gagasan dengan bebas, mereka mampu menuangkan gagasan tetapi terdapat berbagai macam kesalahan dalam penulisannya. Kesalahan tersebut baik dalam bentuk kesalahan ejaan, tata kalimat, atau tata bahasa. Kedua, siswa yang tidak menyiapkan diri sebelum pelajaran dimulai walaupun materi pelajaran yang akan diberikan minggu berikutnya sudah 
diinformasikan oleh guru pengajar. Siswa beranggapan kalau mereka ke sekolah hanya untuk mendengarkan dan mencatat penjelaskan guru saja. Ketiga, metode yang diterapkan dalam pembelajaran selama ini masih didominasi dengan metode ceramah. Guru banyak menceramahkan konsep-konsep, prinsip-prinsip dalam bentuk yang sudah jadi dalam pengajarannya. Hal ini menyebabkan sebagian besar siswa merasa bosan untuk mengikuti pelajaran, sehingga aktivitas belajar siswa menjadi rendah.

Fenomena seperti itu, memerlukan upaya untuk meningkatkan kemampuan menulis siswa. Jangan sampai masalah tersebut menjadi meluas dan akan berulang sampai murid melanjutkan ke jenjang pendidikan yang lebih tinggi atau bahkan dalam pemakaian kehidupan bermasyarakat sehari-harinya.Yang lebih ditakutkan, kualitas pembelajaran bahasa Indonesia akan semakin menurun atau bahkan kita menjadi bangsa yang tidak tahu bahasanya sendiri. Seperti telah dijelaskan diatas, permasalahan dalam pembelajaran menulis karangan deskripsi adalah kurangnya keterampilan membuat kalimat-kalimat deskriptif dan kesalahan dalam kaidah penulisan ejaan maupun tata bahasa.

Berdasarkan uraian di atas, salah satu alternatif yang dapat ditempuh untuk mengatasi permasalahan tersebut adalah penerapan pembelajaran quantum learning. Teori konstruktivis menyatakan bahwa siswa harus menemukan sendiri dan mentransformasikan informasi kompleks, mengecek informasi baru dengan aturan-aturan lama dan merevisinya apabila aturan-aturan itu tidak lagi sesuai. Siswa agar benar-benar memahami dan dapat menerapkan pengetahuan, mereka harus bekerja memecahkan masalah, menemukan segala sesuatu untuk dirinya, dan berusaha dengan susah payah dengan ide-ide yang dimiliki (Trianto, 2007). Model pembelajaran yang berdasar pada pandangan konstruktivistik sangat berguna untuk membantu proses belajar siswa. Latihan yang berasal dari psikologi kognitif dapat membantu siswa untuk mengerti, mengingat kembali dan mengaplikasikan informasi, konsep, dan keahlian yang penting. Hal ini digunakan untuk membuat pelajaran menjadi lebih relevan, mengaktifkan pengetahuan siswa yang terdahulu, membantu mengelaborasi dan mengorganisasi informasi, dan memacu siswa untuk bertanya (Trianto, 2007). 
Pembelajaran kuantum (quantum learning) diciptakan berdasarkan teoriteori pendidikan seperti Accelerated Learning dari Lozanov, Multiple Intelegences dari Garder, Neuro-Linguistic Programming dari Grinder dan Bandler, Experiential Learning dari Hahn, Socratic Inquiry, Cooperative Learning dari Johnson dan Johnson, dan Element of Effective Instruction dari Hanter (De Porter, et al., 2001). Dengan demikian, dapat dicermati bahwa pembelajaran kuantummerupakan intisari dari berbagai teori pembelajaran yang memungkinkan optimalisasi proses dan hasil pembelajaran dengan cara mengupayakan daya tarik pembelajaran, memotivasi siswa belajar, dan menumbuhkan kepercayaan diri siswa melalui pengorganisasian yang dikelola oleh guru. Proses belajar mengajar adalah fenomena yang kompleks. Setiap kata, pikiran, tindakan, asosiasi, dan sampai sejauh mana para praktisi pembelajaran mengubah lingkungan, presentasi, dan mengemas rancangan pembelajaran, sejauh itu pula proses belajar berlangsung. Quantum teaching adalah penggubahan pembelajaran yang meriah dengan segala nuansanya yang menyertakan segala kaitan, interaksi, dan perbedaan yang memaksimalkan momen belajar. Quantum teaching berfokus pada hubungan dinamis dalam lingkungan belajar dan interaksi yang membangun landasan dan kerangka yang kuat untuk belajar.

Terdapat lima prinsip dasar dalam quantum teaching yang mempengaruhi semua aspeknya, yaitu: (1) segalanya berbicara, (2) segalanya bertujuan, (3) pengalaman sebelum pemberian nama, (4) akui setiap usaha, dan (5) jika layak dipelajari, maka layak pula dirayakan (De Porter, et. al., 2001). Prinsip segalanya berbicara, memberi petunjuk bahwa pembelajaran hendaknya memperhatikan segala aspek mulai dari lingkungan kelas, bahasa tubuh, hingga rancangan pembelajaran yang disiapkan, semuanya mengirim pesan tentang belajar. Paradigma pengemasan pembelajaran hendaknya selalu bertolak dari paradigma belajar.Prinsip segalanya bertujuan, memberi petunjuk bahwa semua aspek yang dimasukkan dalam kemasan pembelajaran hendaknya mengacu kepada sasaran pembelajaran itu sendiri. Tujuan pembelajaran memperhatikan apa, kepada siapa, kapan, berapa lama konsep-konsep akan dikaji. Tanpa sasaran yang pasti, kemasan pembelajaran akan menjadi tidak menarik.Prinsip pengalaman sebelum 
pemberian nama, memberi petunjuk bahwa proses belajar paling baik terjadi ketika siswa telah mengalami informasi sebelum mereka memperoleh nama untuk apa mereka pelajari. Rasionalnya, yaitu otak manusia berkembang pesat dengan adanya rangsangan kompleks yang akan menggerakkan rasa ingin tahu. Hal ini perlu memperoleh latihan-latihan intensif. Kekuatan otak yang terlatih akan dapat menggantikan kekuatan otot (Gordon Dryden dan Jeannette Vos, dalam Santyasa, 2001). Prinsip akui setiap usaha, memberi petunjuk bahwa belajar adalah suatu kegiatan yang senantiasa mengandung resiko. Ketika proses belajar terjadi berarti siswa telah melangkah keluar dari rasa kenyamanannya yang alami. Hal ini dikarenakan terjadi interaksi yang kompleks melibatkan mental, intelektual, dan emosionalnya yang akhirnya bermuara pada kelelahan. Oleh sebab itu, siswa hendaknya mendapat pengakuan atas upayanya menggunakan kecakapan dan percaya diri siswa tanpa seluruhnya memperhatikan produk positifnya. Jadi, yang paling diutamakan adalah pengakuan atas proses belajar mereka.Prinsip jika layak dipelajari, maka layak pula dirayakan, memberi petunjuk bahwa perlunya reinforcement dan feedback sebagai wujud pengakuan pendidik terhadap segala kekurangan dan kelebihan siswa. Delapan kunci keunggulan yang juga digunakan dalam pembelajaran kuantum (quantum teaching) ini, yaitu: integritas (kejujuran), kegagalan awal kesuksesan, berbicara dengan niat positif, hidup di saat ini, komitmen, tanggungjawab, sikap luwes atau fleksibel, dan keseimbangan antara pikiran, tubuh dan jiwa. Untuk dapat menanamkan 8 (delapan) kunci keunggulan ini kepada siswa, maka seorang guru haruslah memberikan teladan untuk perilaku yang ingin dilihat pada anak didiknya, menggunakan analogi atau perumpamaan, dan menerapkan dalam proses belajar mengajar.

Kata “Aktivitas” berasal dari Bahasa Inggris 'activity' yang artinya 'state of action, lireliness or ingorous mation'. Apabila diartikan dalam Bahasa Indonesia kata ini berarti kebenaran dari perlakuan, kegiatan yang aktif, kegiatan yang aktual atau giat dalam melakukan gerak-gerik, usul. Dalam bahasa Indonesia aktif berarti giat belajar, giat berusaha, dinamis, mampu berkreasi dan beraksi (Kamus Besar Bahasa Indonesia: 32). 
Aktivitas belajar mempunyai batasan-batasan seperti: 1) kebenaran perlakuan, 2) ada partisipasi, 3) kegiatan aktual atau keikutsertaan baik jasmani maupun rohani, 4) antusiasme, 5) interaksi siswa dengan guru, siswa dengan siswa lainnya, 6) penerapan secara aktual apa yang telah diporoleh.

Menulis adalah kegiatan merangkai kata menjadi kalimat agar dapat dimengerti dan dipahami oleh orang lain yang membacanya dengan tujuan apa yang ditulis dapat memberikan informasi sehingga pembaca seolah-olah berkomunikasi dan mendapatkan manfaat dari kalimat yang dituliskan. Menulis adalah sebuah proses saling memberi informasi dan saling berkomunikasi antar sesama manusia dalam bentuk tulisan. Dengan menulis proses komunikasi berjalan lebih lancar. Dalam KBBI (2003:1219) menulis adalah melahirkan pikiran atau perasaan (seperti mengarang, membuat surat) dengan tulisan.

Jika seseorang melukiskan suatu benda seobjektif mungkin sesuai dengan keadaan yang dilihatnya, karangan seperti ini dinamakan deskripsi realistis (fakta), sedangkan jika peneliti melukiskan suatu benda dengan memasukkan unsur subjektif, peneliti turut menginterpretasi pandangan dirinya terhadap benda yang dilukiskannya, karangan yang ia buat adalah jenis deskripsi impresionistis (fiksi). Ciri karangan deskripsi adalah bahwa tulisan deskripsi mengajak pembaca untuk menikmati, merasakan, memahami, dengan sebaik-baiknya objek, adegan, pribadi, dan suasana hati yang telah dialami oleh pengarang. Tarigan dalam Adhi Widya (2008:24). Masih dalam Adhi Widya (2008:24) Yus Rusyana memberikan ciri deskripsi dengan menggunakan "melukiskan", yang berarti karangan deskripsi harus dapat melukiskan atau menggambarkan objek.

Adapun tujuan penelitian ini adalah sebagai berikut. (1) Untuk mengetahui peningkatan Aktivitas Belajar Siswa Kelas IX B SMP Negeri 2 Kubu Tahun Pelajaran 2017/2018 Melalui Penerapan Quantum Learning (2) Untuk mengetahui peningkatan Kemampuan Menulis Karangan Deskripsi Pada Siswa Kelas IX B SMP Negeri 2 Kubu Tahun Pelajaran 2017/2018 Melalui Penerapan Quantum Learning.

\section{METODE PENELITIAN}


Metode yang digunakan dalam penelitian ini adalah Penelitian Tindakan Kelas (PTK) atau yang biasa disebut Classroom Action Research (CAR) yang bertujuan untuk mengadakan perbaikan dan meningkatkan proses pembelajaran. Menurut Stephen Kemmis (dalam Airlangga, Panji.2007:36), PT Kadalah, "Sebuah bentuk kajian yang bersifat reflektif oleh pelaku tindakan, yang dilakukan untuk meningkatkan kemampuan rasional dan tindakan-tindakan mereka dalam melaksanakan tugas, memperdalam pemahaman terhadap tindakantindakan yang dilakukannya itu, serta memperbaiki kondisi praktek-praktek pembelajaran tersebut dilakukan."

Populasi dalam penelitian ini adalah siswa kelas IX B SMP Negeri 2 Kubu.Subjek dalam penelitian ini adalah siswa kelas IX B SMP Negeri 2 Kubu, yang berjumlah 42 orang siswa. Objek dalam penelitian ini adalah keaktifan dan hasil belajar IPA siswa kelas IX B SMP Negeri 2 Kubu. Variabel penelitian terdiri dari variabel bebas dan variabel terikat. Variabel bebas yaitu pembelajaran quantum learning. Variabel terikat yaitu aktivitas belajar dan kemampuan menulis hasil karangan deskripsi.

Prosedur penelitian yang dilakukan meliputi (1) refleksi awal, peneliti mengkaji masalah-masalah yang dihadapi oleh siswa kelas VII dalam pembelajaran IPA; (2) rencana tindakan; (3) Pelaksanaan tindakan; (4) Observasi, pada kegiatan ini peneliti berpedoman pada pedoman observasi yang telah dilakukan; (5) Evaluasi untuk mengetahui keberhasilan siswa dalam pembelajaran IPA dengan cara memberikan tespembuatan karangan deskripsi; (6) Refleksi dilaksanakan setelah tindakan usai.

Dalam penelitian ini, peneliti menggunakan beberapa teknik pengumpulan data,yaitu observasi, dan lembar kemampuan siswa (tes). Data-data tersebut peneliti kumpulkan selama penelitian berlangsung. Dari data-data tersebutlah, nantinya peneliti akan megetahui sejauh mana keberhasilan pembelajaran menulis karangan deskripsi dengan menggunakan model pembelajaran Quantum Learning.

Aktivitas belajar siswa diambil dengan menggunakan pedoman observasi. Data aktivitas belajar siswa dikumpulkan setiap pertemuan dalam proses 
pembelajaran. Pedoman observasi berisikan 9 indikator aktivitas belajar siswa. Masing-masing indikator dinilai berdasarkan rubrik pada Tabel 1 berikut ini.

Tabel 1. Rubrik Penilaian Aktivitas Belajar

\begin{tabular}{clc}
\hline No & Kriteria Penilaian & Skor \\
\hline 1 & Sering & 3 \\
2 & Sedang & 2 \\
3 & Jarang & 1 \\
\hline
\end{tabular}

Nilai yang diperoleh siswa pada akhir siklus dirata-ratakan kemudian diubah dalam skala seratus, kemudian nilai aktivitas siswa dalam skala seratus tersebut dikategorikan dalam lima skala. Pedoman penggolongan aktivitas siswa dalam pembelajaran dinyatakan dengan Tabel 2 sebagai berikut.

Tabel2.Pedoman Penggolongan Aktivitas Siswa

\begin{tabular}{|c|c|}
\hline Kriteria & Kategori \\
\hline $91-100$ & Sangat Aktif \\
\hline $81-90$ & Aktif \\
\hline $71-80$ & Cukup \\
\hline $61-70$ & Kurang \\
\hline$<60$ & Sangat Kurang \\
\hline
\end{tabular}

Skor rata-rata aktivitas siswa yang diperoleh dari perhitungan dibandingkan dengan skor penggolongan yang telah ditetapkan.Skor rata-rata aktivitas siswa dianalisis dengan rumus:

$$
\overline{\mathrm{X}}=\frac{\sum \mathrm{X}}{\mathrm{N}}
$$

dimana :

$$
\begin{aligned}
\overline{\mathrm{X}} & =\text { skor rata-rata aktivitas siswa. } \\
\sum \mathrm{X} & =\text { jumlah seluruh skor. } \\
\mathrm{N} & =\text { jumlah siswa. }
\end{aligned}
$$

(Arikunto, 2002) 
Skor rata-rata aktivitas siswa yang diperoleh dari perhitungan dibandingkan dengan skor penggolongan aktivitas seperti pada Tabel 3.5.Kriteria keberhasilan penelitian ini adalah jika sikap siswa minimal berada pada kategori aktif.

Data karangan deskripsi diperoleh dari kemampuan siswa membuat karangan deskripsi yang diberikan ada akhir siklus. Indikator penilaian karangan deskripsi terdiri dari 6 indikator yang masing-masing penilaiannya seperti berikut.

KriteriaPenilaian

a. Kesesuaian dengan objek

1 = Objek yang digambarkan tidak sesuai dengan keadan sebenarnya

$2=$ Objek yang digambarkan kurang sesuai dengan keadaan sebenarnya

$3=$ Objek yang digambarkan sesuai dengan keadaan sebenarnya tapi penggambarannya tidak jelas

4 = Objek yang digambarkan sesuai dengan keadaan sebenarnya tapi penggambarannya kurang jelas

5 = Objek yang digambarkan sesuai dengan keadaan sebenarnya dan digambarkan dengan jelas

b. Keterperincianobjek

$1=$ Penggambaran objek tidak rinci dan tidak jelas

$2=$ Penggambaran objek kurang rinci dan kurang jelas

$3=$ Objek terperinci namun tidak digambarkan dengan jelas

$4=$ Objek terperinci namun penggambarannya kurang jelas

5 = Objek terperinci dan penggambarannya secara sistematis/jelas

c. Kelengkapanpancaindera

1 = Tidak ada penginderaan sama sekali

2 = Hanya menggunakan satu jenis penginderaan

3 = Hanya menggunakan dua jenis penginderaan

4 = Hanya menggunakan tiga jenis penginderaan

5 = Menggunakan 4 atau 5 jenis penginderaan 
d. KetepatanDiksi

1 = Pilihan katanya tidak tepat, arti kata kurang sesuai

$2=$ Arti kata sesuai namun banyak pilihan kata yang kurang tepat dan kurang menarik

3 = Ada sedikit pilihan kata yang kurang tepat, arti kata dan bahasanya sesuai tapi gaya bahasanya kurang menarik

4 = Pilihan katanya tepat, arti kata dan bahasanya sesuai, tetapi bahasanya kurang menarik dan kurang bervariasi.

5 = Pilihan katanya tepat, arti kata dan bahasanya sesuai serta memiliki gaya bahasa yang menarik dan bervariasi.

e. Ketepatan ejaan dan tanda baca

$1=$ Pemakaian ejaan tidak tepat dan banyak kesalahan tanda baca

$2=$ Pemakaian ejaan kurang tepat, banyak kesalahan tanda baca yang menunjukkan ketidakcermatan

$3=$ Pemakaian ejaan kurang tepat, sedikit kesalahan tanda baca yang menunjukkan ketidakcermatan

$4=$ Pemakaian ejaan tepat, menguasai aturan penulisan, sedikit kesalahan tanda baca yang menunjukkan ketidakcermatan

$5=$ Tidak ada kesalahan ejaan dan tanda baca.

f. Ketepatan mengembangkan karangan

$1=$ Isi tidak sesuai dengan judul, tidak sesuai dengan objek yang diamati, dan tidak jelas.

$2=$ Isi kurang sesuai dengan judul, kurang sesuai dengan objek yang diamati, dan kurang jelas.

$3=$ Isi cukup sesuai dengan judul, cukup sesuai dengan objek yang diamati, dan cukup jelas.

$4=$ Isi sesuai dengan judul, sesuai dengan objek yang diamati, dan cukup jelas.

$5=$ Isi sangat sesuai dengan judul, sangat sesuai dengan objek yang diamati, dan sangat jelas. 
Data kemampuan menulis karangan deskripsi siswa dianalisis secara deskriptif, yaitu dengan menentukan rata-rata yang diperoleh melalui tes. Setelah diperoleh skor siswa, selanjutnya dicari skor rata-rata $(\bar{X})$ dengan rumus:

$$
\bar{X}=\frac{\Sigma X}{N}
$$

Keterangan:

$\Sigma \bar{X} \quad=$ jumlah skor

$\mathrm{N} \quad=$ banyak siswa

Ketuntasan klasikal dihitung dengan rumus sebagai berikut.

$$
\mathrm{KK}=\stackrel{\sum \mathrm{T}}{=} \times 100 \%
$$

$\mathrm{N}$

Keterangan:

$\mathrm{KK}=$ Ketuntasan Belajar Klasikal

$\sum \mathrm{T}=$ Jumlah siswa tuntas

$\mathrm{N}=$ Jumlah siswa

Siswa dikatakan tuntas jika $\bar{X} \geq 70$ dan satu kelas dikatakan tuntas jika KK $\geq$ 85\%. Hal ini sesuai dengan kriteria yang ditetapkan oleh SMP Negeri 2 Kubu pada semester ini. Penelitian ini dikatakan berhasil jika rata-rata $(\bar{X})$ pencapaian minimal 78 dan ketuntasan klasikalnya (KK) minimal 85\%.

\section{HASIL DAN PEMBAHASAN}

Hasil dan pembahasan akan dijabarkan sebagai berikut:

Hasil

Rata-rata aktivitas belajar siswa yang dicapai pada siklus I adalah 74 dengan standar deviasi 6,7 memiliki aktivitas belajar yang tergolong cukup. Hasil ini masih perlu ditingkatkan, penelitian ini dikatakan berhasil jika rata-rata 
aktivitas belajar siswa berkategori aktif. Sebaran aktivitas belajar siswa kelas IX B disajikan pada Tabel3berikut.

Tabel 3.Sebaran Data Aktivitas Belajar Siklus I

\begin{tabular}{cccc}
\hline Kriteria & Kategori & Frekuensi & Persentase \\
\hline $91-100$ & Sangat Aktif & 0 & $0 \%$ \\
$81-90$ & Aktif & 8 & $19 \%$ \\
$71-80$ & Cukup & 18 & $43 \%$ \\
$61-70$ & Kurang & 16 & $38 \%$ \\
$<60$ & Sangat Kurang & 0 & $0 \%$ \\
\hline
\end{tabular}

Pada siklus I, siswa kelas IX B secara klasikal hanya mencapai rata-rata menulis karangan deskripsi sebesar 70 dengan standar deviasi 11,2 berada pada kualifikasi cukup. Penelitian dikatakan berhasil jika rata-rata kemampuan menulis siswa mencapai rata-rata 78. Sebaran data kemampuan menulis siswa pada siklus I disajikan pada Tabel 4 berikut.

Tabel 4. Sebaran data kemampuan menulis siklus I

\begin{tabular}{ccccc}
\hline $\begin{array}{c}\text { Interval Tingkat } \\
\text { Penguasaan }\end{array}$ & $\begin{array}{c}\text { Kategori } \\
\text { Nilai }\end{array}$ & Keterangan & Frekuansi & Persentase \\
\hline $86-100$ & A & Sangat Baik & 1 & $2 \%$ \\
$70-85$ & B & Baik & 20 & $48 \%$ \\
$50-69$ & C & Cukup & 21 & $50 \%$ \\
$<50$ & K & Kurang & 0 & $0 \%$ \\
\hline
\end{tabular}

Rata-rata aktivitas belajar siswa yang dicapai pada siklus II adalah 86 dengan standar deviasi 3,2tergolong aktif. Hasil ini sudah sesuai dengan kriteria yang ditetapkan yaitu aktivitas belajar siswa berkualifikasi aktif. Sebaran aktivitas belajar siswa kelas IX B disajikan pada Tabel 5 berikut ini. 
Tabel 5. Sebaran data aktivitas belajar siklus II

\begin{tabular}{cccc}
\hline Kriteria & Kategori & Frekuensi & Persentase \\
\hline $91-100$ & Sangat Aktif & 4 & $10 \%$ \\
$81-90$ & Aktif & 38 & $90 \%$ \\
$71-80$ & Cukup & 0 & $0 \%$ \\
$61-70$ & Kurang & 0 & $0 \%$ \\
$<60$ & Sangat Kurang & 0 & $0 \%$ \\
\hline
\end{tabular}

Pada siklus II, siswa kelas IX B secara klasikal hanya mencapai rata-rata menulis karangan deskripsi sebesar 79 dengan standar deviasi 8,5 berada pada kualifikasi baik. Penelitian dikatakan berhasil jika rata-rata kemampuan menulis siswa mencapai rata-rata 78. Sebaran data kemampuan menulis siswa pada siklus II disajikan pada Tabel6 berikut.

Tabel 6. Sebaran Data Kemampuan Menulis Siklus II

\begin{tabular}{ccccc}
\hline $\begin{array}{c}\text { Interval Tingkat } \\
\text { Penguasaan }\end{array}$ & $\begin{array}{c}\text { Kategori } \\
\text { Nilai }\end{array}$ & Keterangan & Frekuansi & Persentase \\
\hline $86-100$ & A & Sangat Baik & 13 & $31 \%$ \\
$70-85$ & B & Baik & 25 & $60 \%$ \\
$50-69$ & C & Cukup & 4 & $10 \%$ \\
$<50$ & K & Kurang & 0 & $0 \%$ \\
\hline
\end{tabular}

Aktivitas belajar siswa siklus I ke siklus II meningkat dari kualifikasi cukup ke kualifikasi aktif. Perbandingan kualifikasi data aktivitas belajar disajikan pada Tabel 7 berikut.

Tabel 07 Kualifikasi Data Aktivitas Belajar Siklus I Dan II

\begin{tabular}{cccccc}
\hline \multirow{2}{*}{ Kriteria } & \multirow{2}{*}{ Kategori } & \multicolumn{2}{c}{ SIKLUS I } & \multicolumn{2}{c}{ SIKLUS II } \\
& & Frekuensi & Persentase & Frekuensi & Persentase \\
\hline $91-100$ & Sangat Aktif & 0 & $0 \%$ & 4 & $10 \%$ \\
$81-90$ & Aktif & 8 & $19 \%$ & 38 & $90 \%$ \\
$71-80$ & Cukup & 18 & $43 \%$ & 0 & $0 \%$ \\
& & & & & Jurnal IKA | 63
\end{tabular}


Jurnal IKA Vol. 17, No.1 Maret 2019

ISSN 1829-5282

\begin{tabular}{cccccc}
$61-70$ & Kurang & 13 & $38 \%$ & 0 & $0 \%$ \\
$<60$ & Sangat & & & & \\
& Kurang & 0 & $0 \%$ & 0 & $0 \%$ \\
\multicolumn{2}{c}{ Rata-rata } & 70 & Cukup & 86 & Aktif \\
Standar Deviasi & 11.2 & & 3.2 & \\
\hline
\end{tabular}

Pada siklus I rata-rata kemampuan menulis karangan deskripsi siswa adalah 70 dengan kualifikasi cukup. Siklus II rata-rata kemampuan menulis karangan deskripsi siswa adalah 79 dengan kualifikasi baik. Hal ini menunjukkan terjadi peningkatan rata-rata kemampuan menulis karangan deskripsi siswa dari siklus I ke siklus II.

Jika dikualitatifkan kemampuan menulis karangan deskripsi siswa siklus I ke siklus II meningkat dari kualifikasi cukup ke kualifikasi baik. Perbandingan kualifikasi data kemampuan menulis karangan deskripsi disajikan pada Tabel 8 berikut.

Tabel 8 Kualifikasi Kemampuan Menulis Karangan Deskripsi Siklus I Dan II

\begin{tabular}{lllllll}
\hline $\begin{array}{l}\text { Interval } \\
\text { Tingkat }\end{array}$ & Kategori & Keterangan & \multicolumn{2}{l}{ SIKLUS I } & \multicolumn{2}{l}{ SIKLUS II } \\
Penguasaan & Nilai & & $\mathrm{f}$ & $\%$ & $\mathrm{f}$ & $\%$ \\
\hline $86-100$ & $\mathrm{~A}$ & Sangat Baik & 1 & $2 \%$ & 13 & $31 \%$ \\
$70-85$ & $\mathrm{~B}$ & Baik & 20 & $48 \%$ & 25 & $60 \%$ \\
$50-69$ & $\mathrm{C}$ & Cukup & 21 & $50 \%$ & 4 & $10 \%$ \\
$<50$ & $\mathrm{~K}$ & Kurang & 0 & $0 \%$ & 0 & $0 \%$ \\
\hline
\end{tabular}

\section{Pembahasan}

Pada siklus I rata-rata aktivitas siswa sebesar 70 dengan kategori cukup dan rata-rata kemampuan menulis karangan deskripsi sebesar 70 dengan kategori cukup. Dalam hal ini hasil pada siklus I belum mencapai kriteria yang ditetapkan. Ini disebabkan karena adanya kekurangan-kekurangan pada siklus I diantaranya : 
a. Kebanyakan siswa masih belum mengerti perbedaan karangan deskripsi dengan karangan lainnya.

b. Masih belum bisa menggambarkan objek dengan jelas dan terkadang tidak sesuai dengan objek yang diamati

c. Hanya menggunakan satu pancaindera

d. Pemilihan diksi yang kurang

e. Masih terdapat banyak kesalahan dalam memakai ejaan dan tanda baca padahal sudah diingatkan.

f. Masih belum bisa mengembangkan karangan dengan baik.

Perbaikan tindakan yang dilakukan pada siklus II adalah sebagai berikut.

a. Menjelaskan kembali mengenai karangan deskripsi dan memberikan contoh lain yang dapat dimengerti siswa. Kemudian memberikan contoh mengenai karangan deskripsi yang bersifat fakta dan fiksi.

b. Memberikan contoh cara merinci objek yang akan dideskripsikan.

c. Mengajak siswa untuk memakai seluruh panca inderanya dalam menuangkan kata-kata dalam karangannya, dengan cara mengamati langsung objek yang akan dideskripsikan.

d. Menerangkan kembali secara singkat tentang cara menentukan atau mengelompokkan ide, menulis cepat, menunjukkan bukan memberitahu (mendeskripsikan karangan), dan memperbaiki penelitian

e. Memotivasi siswa dengan membacakan karangan siswa yang sudah lumayan bagus agar dapat menarik siswa yang lain untuk meniru keberhasilan temannya.

f. Menegaskan kepada siswa untuk menerapkan ejaan dan tanda baca yang tepat dalam karangan yang mereka buat, karena pada dasarnya mereka mengerti tentang cara penelitian tetapi mereka malas menerapkannya.

g. Membuat pelajaran lebih menarik dan tidak monoton.

h. Lebih menguasai materi pembelajaran dan berusaha menguasai kelas.

i. Lebih baik lagi dalam mengalokasikan waktu.

j. Meyakinkan siswa dengan memberikan motivasi bahwa semuanya adalah peneliti dan semua pasti bisa asal berusaha. 
Berdasarkan perbaikan-perbaikan yang dilakukan pada pembelajaran siklus II terjadi peningkatan aktivitas dan kemampuan siswa dalam menulis karangan deskripsi. Rata-rata aktivitas siswa pada siklus II menjadi 86 dengan kategori aktif dan rata-rata kemampuan menulis karangan deskripsi sebesar 79 dengan kategori baik. Dengan demikian hasil pada siklus II sudah memenuhi kriteria yang sudah ditetapkan dan penelitian dikatakan berhasil sehingga Quantum Learning dapat dijadikan salah satu alternatif pembelajaran yang dapat mengkonstruksikan pemahaman siswa ke arah yang lebih baik.

Pembelajaran Quantum Learning dapat memotivasi siswa untuk berbuat yang terbaik dan selalu berusaha untuk meningkatkan kemampuan individu yang akan berimbas pada peningkatan kualitas kelompok siswa tersebut karena adanya penghargaan terhadap prestasi belajar siswa. Pembelajaran Quantum Learning dapat mengurangi sifat egois dan individualisme yang terjadi pada siswa. Siswa dibentuk dalam suatu kelompok yang heterogen dan dituntut untuk menyelesaikan permasalahan secara bersama-sama dalam kelompok tersebut, sehingga setiap anggota kelompok termotivasi untuk belajar sebaik-baiknya dalam pembelajaran. Siswa yang mempunyai motivasi yang kuat, maka akan menunjukkan minat, aktivitas, dan partisipasinya dalam pembelajaran dan akhirnya semua akan bermuara pada peningkatan prestasi belajar yang ingin dicapai.

Implementasi model pembelajaran Quantum Learning dalam proses pembelajaran akan membuat pembelajaran lebih bermakna bagi siswa dan memiliki orientasi dalam mengingat pengetahuan jangka panjang. Siswa diposisikan dalam suatu kelompok Quantum Learning untuk bersama-sama saling memberikan masukan dan motivasi terhadap sebuah permasalahan guna menggali informasi yang relevan terhadap permasalahan yang dihadapi sehingga tujuan bersama dalam kelompok untuk memajukan hasil belajar tiap anggota kelompok dapat terwujud. Implementasi model pembelajaran Quantum Learning juga mampu mendidik siswa untuk belajar berbicara di depan kelas dan belajar menghargai pendapat orang lain melalui diskusi kelas, sehingga keterampilan dan sikap siswa akan berkembang dan pada akhirnya akan memberikan pengaruh positif terhadap aktivitas dan kemampuan menulis karangan siswa. 


\section{UCAPAN TERIMAKASIH}

Ucapan terimakasih yang sebesar-besarnya ditujukan kepada (1) Drs. I Nengah Suda, M.Pd.H selaku kepala sekolah dan (2) rekan guru yang telah memberikan dukungan dan motivasi kepada penulis

\section{DAFTAR RUJUKAN}

Abdul, 2002 dalam http://www.scribd.com/doc/90372081/

Airlangga, Panji. 2007. Penggunaan Media Realita sebagai Upaya MeningkatkanPembelajaran Keterampilan Menulis Deskripsi. Skripsi pada Program Pendidikan

Bahasa danSastraIndonesiaFPBSUPIBandung:tidak diterbitkan.

Arikunto, Suharsimi, 2002. Penelitian Tindakan Kelas. Jakarta: PT Bumi Aksara.

Arikunto, Suharsimi. 2006. Dasar-Dasar Evaluasi Pendidikan. Jakarta: Bumi Aksara.

Arikunto, Suharsimi; Suhardjono; Supardi. 2006. Penelitian Tindakan Kelas. Jakarta: PT Bumi Aksara.

Arikunto, Suharsimi. 2007. Penelitian Tindakan Kelas. Jakarta: Bumi Aksara. Anggraeni, Lufi Novita. 2008. Penggunaan Metode Sugestopedia sebagai upaya Meningkatkan Kemampuan Menulis Karangan Deskripsi pada siswa kelas X SMA Negeri 15 Bandung Tahun Pelajaran 2007/2008. Skripsi pada Program Pendidikan Bahasa dan Sastra Indonesia FPBSUPI Bandung : tidak diterbitkan.

De Porter, Bobbi. 2008. Quantum Learning Membiasakan Belajar Nyaman dan Menyenangkan. Bandung: Kaifa.

Iskandar.2009. Penelitian Tindakan Kelas. Cipayung. Gaung Persada.

Keraf,Gorys.1981.Eksposisi dan Deskripsi. Flores: Arnodus Ende.

Lorsbach, A., Tobin, K. 1997. Constructivism as a Referent for Science Teaching. Dapat diakses pada: http:// www.exploratorium.edu/ ifi/resources/ research/ constructivism.html (1)

Nasir, Moh. 2003. Metode Penelitian. Jakarta : Ghalia Indonesia

Nurhayati, 1998. "Integrasi Proses Membaca dan Menulis dalam Meningkatkan Kemampuan Menulis”. Jurnal Bahasa dan Sastra Lingua, Volume 2 Nomor 1, 13 (Balai Bahasa Palembang). 
R Adhi, Widya. 2008. Penerapan Teknik Show Not Tell untuk Meningkatkan Kemampuan Menulis Karangan Deskripsi (Penelitian Tindakan Kelas terhadap Siswa SMA Negeri 7 Bandung Kelas X Tahun Ajaran 2007/2008). Skripsi pada Program Pendidikan Bahasa dan Sastra Indonesia FPBSUPI Bandung: tidak diterbitkan.

Sadia, I W. 2003. Konstruktivisme dalam belajar mengajar. Diktat perkuliahan. Jurusan Pendidikan Fisika, FPMIPA, IKIP Negeri Singaraja

Santyasa, I W. 2001. Pengaruh Model dan seting Pembelajaran terhadap Remidiasi Miskonsepsi, Pemahaman Konsep, dan hasil belajara fisika pada Siswa SMU. Disertasi (tidak diterbitkan). Program Pasca Sarjana, Undiksha.

Sriyono, 1992: http://www.scribd.com/doc/90372081

Suastra, I W. 2002. Strategi Belajar Mengajar Sains. Buku Ajar. Jurusan Pendidikan Fisika Institut Keguruan dan Ilmu Pendidikan Negeri Singaraja.

Suparno, P. 1997. Filsafat Konstruktivisme dalam Pendidikan. Yogyakarta: Penerbit Kanisius.

Tarigan, Henry Guntur. 1982. Menulis sebagai suatu Keterampilan Berbahasa. Bandung: Angkasa.

Trianto. 2007. Model-model Pembelajaran Inovatif Berorientasi Konstruktivistik. Jakarta: Prestasi Pustaka Publisher.

Wibowo, Wahyu. 2007. Menjadi Penulis dan Penyunting Sukses : Langkah Jitu Merangkai Kata Agar Komunikatif, Hidup, dan Memikat. Jakarta: BumiAksara.Widjono. 2007. Bahasa Indonesia Mata Kuliah Pengembangan Kepribadian di Perguruan Tinggi. Jakarta: Grasindo.

Widjono, HS. 2007. Bahasa Indonesia Mata Kuliah Pengembangan Kepribadian di Perguruan Tinggi. Yogyakarta : Grasindo. 